\title{
Geographical distribution of events in the Ukrainian media discourse on Muslims: othering mechanisms
}

\author{
O. Dziuba \\ V. N. Karazin Kharkiv National University \\ Corresponding author. E-mail: lickea83@gmail.com
}

Paper received 06.04.20; Accepted for publication 22.04.20.

\begin{abstract}
https://doi.org/10.31174/SEND-HS2020-231VIII39-15
\end{abstract}
\begin{abstract}
Geographical distribution of media coverage on Muslims-related events is connected to their symbolic position. The main aim of the paper is to discuss a procedure for the discourse analysis quantitative stage, as well as to present the geographical analysis results of a study of the Ukrainian press discourse on Muslims. The empirical basis of the paper is a corpus of over 4000 articles published in the Uriadovy Kurier, Dzerkalo Tyzhnia, Radio Svoboda Ukraina, Segodnia and Vesti from 2010 to 2018.
\end{abstract}

Keywords: Muslims, quantitative stage of discourse analysis, othering mechanisms, geographical distribution, Ukrainian press.

Introduction. Muslims represent about $1 \%$ of Ukrainian population [1]. There are both Ukrainian citizens and immigrants among them. The majority of Ukrainian Muslims are Crimean Tatars. There are other Muslim communities (Turks, Chechens, etc.) in Kherson and Donetsk regions, and in Kyiv too. Immigrants from the former Soviet republics, such as Uzbekistan, Kazakhstan, Azerbaijan, tend to embrace the ancestral religion, and some ethnic Ukrainians convert to Islam as well. Finally, there is a number of Muslim students in several Ukrainian cities. Due to a relatively small percentage of Muslims in Ukraine, the media are an important source of information about them. As mentioned in my previous publication [2]) the media portray Muslims as a distinct group with certain characteristics, and influence their social perception, social inclusion or exclusion.

It is important to describe the Ukrainian media discourse on Muslims according to their place on the symbolic scale between 'Alien, clearly non-Ukrainian' and 'Ordinary Ukrainian'. Such symbolic positioning is closely connected to the geographical distribution of media coverage. V. Kulyk, citing P. Golding and P. Elliott, points out that the proximity of an event to the reader's place of residence has special importance, since the audience '...wants to know how they are doing, then how the neighbors are doing, and only after that about the rest...' [3, p. 158]. 'Theirs' is perceived as important and interesting, while 'the rest' has less to do with 'them', is less familiar. Thus, I consider the media focusing mainly on Islam-related events abroad as an encouragement to treat Muslims as 'strangers'. Since publications in question may describe events both in Ukraine and elsewhere, it is important to calculate their ratio analyzing different editions over a period of time. Localization of an event will serve as the touchstone.

Another research focus is detection of othering mechanisms. According to I. Soroka, othering is the practice of distancing from the Other [4, p. 126]. An important mechanism consists in marking the behavior of the Other as incomprehensible and abnormal. In addition, V. Kulyk lists such mechanisms of othering as: representation of Others as a homogeneous group, describing them with vocabulary commonly used for inanimate objects ('migra- tion flow', for example), and rejection of their agency [5, p. 399]. Detection of othering mechanisms helps answer the question: do they take part in the construction of the 'Muslim' sign in the Ukrainian media?

There are few discourse-oriented studies by Ukrainian sociologists; those concerned with discourse on Muslims are even fewer; therefore, the results of our analysis will contribute to discourse analysis driven studies in Ukrainian sociology and to Islamic studies internationally.

The relevant literature overview. There are many papers devoted to the discourse analysis on Muslims abroad. Truly outstanding among them are those of the British linguists T. McEnery and P. Baker [6], and the Brazilian scholar R. S. Moraes [7]. They make a thorough analysis of the media discourse on Muslims.

In Ukraine the work by V. Kulik has gained much attention. The Ukrainian media discourse is analyzed there in detail, including the press discourse. Another researcher, A. Bezverkha has studied the media discourse on the Crimean Tatars [8]. Her main focus is on the TV discourse.

It should be noted that there are very few papers on discourse analysis that present the results of processing a large amount of text data without computer processing techniques. Here we offer a possible approach to the quantitative phase of discourse analysis with the transition to the qualitative phase.

The objective is to present a procedure for the discourse analysis quantitative stage and to show the geographical analysis results of the discourse on Muslims in the Ukrainian press.

Materials and methods. My previous publication [9] describes in detail the data collection procedure and the subsequent analysis. Text data come from articles from the online versions of five Ukrainian periodicals: Uriadovy Kurier (a government newspaper, hereinafter 'UK'), Radio Svoboda Ukraina (American-funded, hereinafter 'RSU'), Vesti (Russia-funded), Segodnia (belongs to an oligarch), Dzerkalo Tyzhnia (independent, hereinafter 'DT'). The articles were collected via the internal search engines from all the publications citing Muslims. There are 4068 of them in the selected period (from January 1, 
2010, to December 31, 2018). The study design plan includes quantitative and qualitative stages of analysis.

The results. A possible method of processing the body of publications is to divide it into parts. Every part will be analyzed separately, since it describes a discourse concerning a different side of the research object.

In our case there are texts both centered on Muslims and with a passing mention of them. The latter will be treated separately, since we regard them as the object of a forthcoming study. The former can also be divided into four geographical parts. The first part with the working title 'Ukraine' corresponds to Muslim-related events occurring in Ukraine, the second part entitled 'Abroad' refers to foreign events of that kind, the third part entitled 'World and Ukraine' has to do with relations between Ukraine and Islamic countries, and the fourth part, 'General', contains publications on Muslims as followers of Islam, regardless of where they live. This part includes articles about the rivalry between the Sunni and the Shia, for example, or the Islamic culture (holidays, customs, traditions etc).

The distribution of publications on Muslims according to this four-part framework is presented in Table 1, with parenthesized percentages (by row). The column 'Ukraine' also shows the number of publications exclusively on Crimea and the DPR / LPR.

Table 1. Number and proportion of Muslim-related publications in the Ukrainian press by location

\begin{tabular}{|c|c|c|c|c|c|c|c|c|c|c|}
\hline \multirow[b]{2}{*}{ Edition } & \multicolumn{3}{|l|}{ Ukraine } & \multirow[b]{2}{*}{$\begin{array}{l}\text { Total } \\
\text { Ukraine }\end{array}$} & \multirow[b]{2}{*}{$\begin{array}{l}\text { World and } \\
\text { Ukraine }\end{array}$} & \multirow[b]{2}{*}{ Abroad } & \multirow[b]{2}{*}{ General } & \multirow[b]{2}{*}{$\begin{array}{l}\text { World (excluding } \\
\text { those with no } \\
\text { reference to Muslims) }\end{array}$} & \multirow[b]{2}{*}{$\begin{array}{l}\text { No refer- } \\
\text { ence to } \\
\text { Muslims }\end{array}$} & \multirow[b]{2}{*}{ Tota } \\
\hline & $\begin{array}{l}\text { Ukraine } \\
\text { without } \\
\text { Crimea }\end{array}$ & Crimea & $\begin{array}{l}\text { DPR/ } \\
\text { LPR }\end{array}$ & & & & & & & \\
\hline UK & $5(5 \%)$ & $6(6 \%)$ & 0 & $11(11 \%)$ & $6(6 \%)$ & $57(55 \%)$ & $9(9 \%)$ & $83(80 \%)$ & $21(20 \%)$ & 104 \\
\hline RSU & $69(3 \%)$ & $\begin{array}{l}541 \\
(25 \%)\end{array}$ & $\begin{array}{l}10 \\
(0,5 \%)\end{array}$ & $620(29 \%)$ & $30(1 \%)$ & $1159(54 \%)$ & $40(2 \%)$ & $1849(76 \%)$ & $296(14 \%)$ & 2145 \\
\hline Vesti & $24(4 \%)$ & $\begin{array}{l}58 \\
(10 \%)\end{array}$ & 0 & $82(13 \%)$ & $26(4 \%)$ & $349(57 \%)$ & $18(3 \%)$ & $475(78 \%)$ & $\begin{array}{l}136 \\
(22 \%)\end{array}$ & 611 \\
\hline DT & $16(2 \%)$ & $48(6 \%)$ & 0 & $64(8 \%)$ & $7(1 \%)$ & $554(73 \%)$ & $18(2 \%)$ & $643(84 \%)$ & $119(16 \%)$ & 762 \\
\hline $\begin{array}{l}\text { Segod- } \\
\text { nia }\end{array}$ & $35(8 \%)$ & $\begin{array}{l}44 \\
(10 \%)\end{array}$ & 0 & $79(18 \%)$ & $8(2 \%)$ & $318(71 \%)$ & $31(7 \%)$ & $436(98 \%)$ & $10(2 \%)$ & 446 \\
\hline Total & $149(4 \%)$ & $\begin{array}{l}697 \\
(17 \%)\end{array}$ & $\begin{array}{l}10 \\
(0,3 \%)\end{array}$ & $856(21 \%)$ & $77(2 \%)$ & $2437(60 \%)$ & $\begin{array}{l}116 \\
(3 \%)\end{array}$ & $3486(86 \%)$ & $582(14 \%)$ & 4068 \\
\hline
\end{tabular}

The highest percentages in each column are shown in bold. Obviously, by the percentage of publications with a passing mention of Muslims Vesti takes the lead (22\% of all publications with the word 'Muslims'), and Segodnia brings up the rear, with only $2 \%$ of such articles. There are relatively few 'General' articles on Muslims in all the analyzed media. The highest percentage $(9 \%)$ of such articles is in $U K$, and the smallest $(2 \%)$ in $R S U$ and $D T$. The publications describing Ukrainian foreign relations show a similar distribution. Muslim-related events constitute the subject of $6 \%$ of publications in $U K$, while their rate in $R S U$ and $D T$ is only $1 \%$. RSU has published the most articles about Ukrainian Muslims (a large part of those concerns Muslims in Crimea), with a rate of $29 \%$. The least enthusiastic over Muslim-related events in Ukraine is DT (only 8\%).

Muslim-related events abroad take the spotlight in more than half of such publications in all the analyzed media. The highest percentage of them is in DT $(73 \%)$, the lowest in $R S U$ (54\%). This fact indicates that the Islamic world is presented in the media discourse as something external to Ukraine.

The 'World' presented as 'other foreign countries' is discursively heterogeneous and hierarchical. The Ukrainian media discourse is clearly focused on the 'Western world', which is understood primarily as Europe and the USA. The 'Western world' is opposed to the 'East', which has its own way of life, rejects the 'Western' values, and is often hostile to the 'West'. The 'East' is mainly associated with the Islamic world. As for the African countries, such expressions as 'a third world country' (totally legitimate) or the persistent trope 'we are ranked somewhere near Zimbabwe and the like' show the place of Africa in Ukrainian discursive space.

Table 2. Number and proportion of Muslim-related publications by coverage of different parts of the world.

\begin{tabular}{|c|c|c|c|c|c|c|c|c|c|}
\hline \multirow[b]{2}{*}{ Edition } & \multirow[b]{2}{*}{ World } & \multirow[b]{2}{*}{ Australia } & \multirow[b]{2}{*}{ Asia } & \multirow[b]{2}{*}{ Africa } & \multirow[b]{2}{*}{ Europe } & \multirow[b]{2}{*}{ North America } & \multicolumn{3}{|l|}{ Other } \\
\hline & & & & & & & Russia & $\begin{array}{l}\text { Islamic } \\
\text { world }\end{array}$ & Organizations \\
\hline UK & 57 & 0 & $21(37 \%)$ & $18(32 \%)$ & $6(11 \%)$ & $8(14 \%)$ & $3(5 \%)$ & $1(2 \%)$ & 0 \\
\hline RSU & 1159 & $1(0,1 \%)$ & $468(40 \%)$ & $101(9 \%)$ & $383(33 \%)$ & $128(11 \%)$ & $50(4 \%)$ & $9(1 \%)$ & $19(2 \%)$ \\
\hline Vesti & 349 & $1(0,3 \%)$ & $103(30 \%)$ & $44(13 \%)$ & $83(24 \%)$ & $64(18 \%)$ & $34(10 \%)$ & 0 & $20(6 \%)$ \\
\hline DT & 554 & 0 & $136(25 \%)$ & $144(26 \%)$ & $120(22 \%)$ & $70(13 \%)$ & $39(7 \%)$ & $3(1 \%)$ & $42(8 \%)$ \\
\hline Segodnia & 314 & $2(0,6 \%)$ & $116(37 \%)$ & $35(11 \%)$ & $70(22 \%)$ & $40(13 \%)$ & $32(10 \%)$ & $8(3 \%)$ & $15(5 \%)$ \\
\hline Total & 2437 & $4(0,2 \%)$ & $844(35 \%)$ & $342(14 \%)$ & $662(27 \%)$ & $310(13 \%)$ & $158(7 \%)$ & $21(1 \%)$ & $96(4 \%)$ \\
\hline
\end{tabular}


Table 2 presents the number and percentage (by row) of Muslim-related publications of media coverage by geographical distribution. The column 'Other' includes publications about events in Russia (Russia lies on two continents, and, as the largest and most important Ukrainian neighbor, is always an essential part of Ukrainian media discourse to be explored separately), or in the 'Islamic world' (journalists use this term, though few of them could tell how many countries it encompasses) without naming the country, or publications concerned with the activities of certain organizations (al-Qaeda, ISIL, Boko Haram, UN and others).

According to the data above, South American Muslims are perceived as having no importance, because there are no publications about them. Few Muslim-related events take place in Australia (less than 1\%). Such events usually occur in Asia (from $25 \%$ of all DT's publications on Muslims abroad up to $40 \%$ in $R S U$ ) and Europe (from $11 \%$ in $U K$ up to $33 \%$ in $R S U$ ). Articles about African and North American Muslim-related events show approximately the same percentage (14 and 13\%). The events in Russia are primarily described by Vesti and Segodnia (10\% of all publications about Muslims abroad). The actions of such organizations as ISIL or al-Qaeda are connected to Muslims mostly in the publications of DT (8\%) and Vesti $(6 \%)$, compared to lower percentages of such publications in $R S U(2 \%)$ and $U K(0 \%)$.

Thus, from the geographical distribution of events in the media discourse on Muslims one can deduce a focus on coverage of events in Asia or with the participation of Asian countries. If a Ukrainian journalist writes about Muslims, the text will most likely describe events abroad, especially in Asia.

To identify mechanisms of othering, we have analyzed the headlines concerning events in Asia. Titles were chosen randomly: the first publication, the last one and one in the middle of the array for each edition (ranged by date). One of such mechanisms, according to I. Soroka [4, p. 126], lies in qualifying the Other's behavior as abnormal.

$U K$ headlines refer to events in Asia linked to violence or natural anomalies. Such a headline as 'No war against Syria planned' (August 3, 2011) normalizes armed conflict in Syria, assuming that a war can be planned or unplanned, and therefore is made possible by someone whose significance is far higher than that of Syrian citizens. Such coverage also conceals the diversity of Syrians, portraying the country as a single entity and an object of someone's actions.

'Terrorist attack against the Shia in Pakistan: dozens of casualties' (February 18, 2013) is another $U K$ headline and an example of transforming a violent act into a natural phenomenon, a disaster which happened by itself. Neither the actors nor the causes are mentioned, only the result is emphasized. The generalized 'dozens' makes the death toll even more abstract. It doesn't seem to matter how many people died. The word 'casualties' is another way of distancing from tragedy and showing no compassion for the victims. The word 'people' instead would have been able to elicit sympathy.

'Pakistan's heat wave killed more than a thousand people' (June 25, 2015). In this headline, a natural phenomenon is presented as the subject of action. That leads us away from questioning the actions of the authorities, which hadn't taken sufficient measures to mitigate adverse impact of the heat wave. At the same time, it strengthens the association of Pakistan with something mortally dangerous.

$R S U$ headings also employ mechanisms of othering: presentation of Muslims as a homogeneous group and describing their 'abnormal' behavior. Thus, the headline 'Explosions in the Southern Thailand killed 2 people' (January 7, 2010) transforms someone's action into an event. Explosions do not occur without human intervention, but there is no mention of it in the headline. There is also the second mechanism of othering, that of 'abnormalizing' an event.

'Iran will support Iraq in its struggle against Islamists: Rouhani' (October 21, 2014). There we see another generalized reference to countries as subjects of action. No mention of the decision-makers means that intentions and wishes of citizens and authorities are the same. The words 'struggle' and 'Islamists' discursively link Iran and Iraq and underscore the abnormality of events in these countries, connecting Muslims to the phenomenon of Islamism.

'Iranian President urges Muslims to unite against the USA' (November 24, 2018). In this headline, the president of Iran addresses his speech to all Muslims, uniting them into a homogeneous group through their religious affiliation. The word 'against' implies confrontation, and together with the acronym 'USA' reinforces the widespread notion of the conflict between the West, whose embodiment are the United States, and the East, the 'Islamic world'.

The headlines of Vesti have a tendency towards provocation and infotainment. For example, the headline 'In Kazakhstan, it is proposed to execute presidents when they grow old' (May 7, 2013) refers to a non-standard situation, 'a scoop'. At the same time, it shows the abnormality of usual behavior in a Muslim country. Such a headline supports the image of the East as uncivilized and violent.

'Malaysian Muslims banned from playing Pokémon Go' (August 8, 2016), a rather peculiar headline. Malaysia is a predominantly Muslim country, which is not widely known. Is that the reason why the author thought it is necessary to emphasize this fact in order to connect the event with Muslims? Does the ban apply only to Muslims, with non-Muslims and atheists still being allowed to play? In this title Muslims are bound by prohibitions and restrictions. Pokémon Go is an ultramodern augmented reality game, a state-of-the-art technology. Therefore Muslims look out of touch and retrograde.

'Time names the Saudi journalist Khashoggi the person of the year' (December 11, 2018). From this headline, the reader finds out that there is journalism in Saudi Arabia and, at the same time, that the Saudi journalist died a violent death. The combined implications support the notion of the uncivilized and prone to violence East.

$D T$, in unison with other Ukrainian editions, describes events in Asia as related to violence. 'A hot Turkish Summer 2010: The Army on the defensive' (September 3, 2010) and 'The media report that Russian cruise missiles fell in Iran' (October 8, 2015) are examples of headlines linking Islamic countries to war. The words 'army', 'de- 
fensive' and 'cruise missiles' imply hostilities, indicating abnormal conditions in those countries.

'The US Congress accuses Myanmar of genocide against Rohingya Muslims' (December 14, 2018) is another DT headline. The US Congress is accusing another country of serious crime and these accusations are relevant to $D T$. The word 'genocide' has a strong negative sense, meaning death of a large number of people, an abnormal and dangerous situation. Muslims in this title do not appear collectively, as Muslims in general, but as a part, namely 'Rohingya Muslims'. A headline without this clarification would have taken a different meaning. Compare: 'The US Congress accuses Myanmar of genocide against Muslims'. With it, however, the victims of Myanmar are not just Muslims, but a special kind of them. Other Muslims are not victims. The headline 'Terrorist attack against the Shia in Pakistan' was cited above. The Shia are also Muslims, but there is no 'terrorist attack on Muslims' in the headline. Therefore, the Ukrainian media do not always generalize Muslims when violent acts are directed against them.

Instead, a similar headline of Segodnia 'The UN accuses Myanmar of genocide against Muslims' (August 27, 2018), portrays Muslims as a homogeneous group. The same word 'genocide' is used, but there is neither 'Rohingya' nor another ethnonym. However, we can detect there such a mechanism of othering as the refusal of agency.

Two other randomly selected titles of Segodnia also refer to violence and accidents. The headline 'A bus with Azerbaijani pilgrims has capsized in Turkey' (November 24, 2010) tells us about an accident that happened to, most likely, Muslims from Azerbaijan. The author deems it necessary to emphasize that the passengers were pilgrims, which marks them as believers who traveled specifically to worship. The bus seems to be the subject of action, as if it crashed by itself. The headline does not ascribe importance to the reason of the accident, but to persons affected by it. Therefore it distracts readers from finding out the culprits, and focuses their attention on the reasons of the trip.

'New clashes in Jerusalem: 56 people injured' (July 27, 2017). The headline doesn't mention Muslims, though the word 'new' implies that similar bouts of violence have already occurred. Since readers are aware of the conflict between Israeli Jews and Arabs, they can easily construe the intended meaning. The exact number of victims and the word 'people' show some degree of sympathy. It is not clear from the title who exactly suffered and with whom we ought to sympathize.

Thus, the analysis strongly suggests that in the Ukrainian press Muslims are mentioned mainly in connection with conflicts, accidents, confrontation, violence and death. Muslims can act as subjects or objects of violence or confrontation. However, due to discursive mechanisms, such coverage always leads to exclusion. The authors of the headlines employ such mechanisms of othering as emphasis on behavioral abnormalities, portrayal of Muslims as a homogeneous group, denial of their agency.

Conclusions. One way of processing an array of texts is to divide it into meaningful parts, with every part highlighting a different side of the discourse object. The next stage is to investigate randomly selected articles. For a study of discourse on Muslims in the Ukrainian press, the array has been divided by geographical distribution of the coverage.

The Ukrainian media discourse tends to present Muslims as foreigners. The percentage of Muslim-related articles on Asia is the highest. The analysis of headlines shows that Muslims are associated with violence, conflict and confrontation. Mechanisms of othering constitute a visible part of the Ukrainian media discourse on Muslims.

\section{REFERENCES}

1. Pew Research Center. Washington, 2017. Retrieved from: https://www.pewresearch.org/fact-tank/2017/11/29/5-factsabout-the-muslim-population-in-europe/

2. O. Dziuba. The thematic structure of the Discourse \& Society: how did the 'Muslims issue' appear // Ukrainian Sociological Journal

3. V. Kulyk. Media and Identity. ResPublica, 2010. Retrieved from:

http://prima.lnu.edu.ua/Subdivisions/um/um_15/15_pdf/12_U M_15_MediiIdent_Kulyk.pdf

4. I. Soroka. The native, the strange, the different: a sociocultural perspective on the perception of the Other. V.N. Karazin Kharkiv national university, 2012. 332 p.

5. Kulyk V. The Ukrainian Media Discourse: Identities, Ideologies, Power Relations. Kyiv Krytyka, 2010.

6. P. Baker. Discourse analysis and media attitudes: Gabrielatos, T. McEnery. - Cambridge University Press, 2013. - 281 p.

7. R. S. de Moraes. O discurso sobre o muçulmano na imprensa brasileira: o caso da revista Veja / R. S. de Moraes. - Dis. Universidade de São Paulo, 2011. - 202 p.

8. A. Bezverkha. Reinstating Social Borders between Slavic Majority and the Tatar Population of Crimea: Media Representation of Contested Memory of the Crimean Tatars' Deportation // Journal of Borderlands Studies. - 2017. — № 2. - P. 127-139

9. O. Dziuba. Features of the development of a research plan for Muslims discourse analysis of the Ukrainian press // Grani, 2019. P. 55 